\title{
Covid-19 Salgınının Türkiye'nin Dış Ticaretine Etkisi: Bir Yapısal Kırılma Analizi
}

\section{Erdem ATEŞ ${ }^{1}$}

Özet

2019 yılının Aralık ayında Çin'in Wuhan şehrinde ortaya çıkan Covid-19 virüsü 2020 yılı ile küresel bir salgına dönüşmüştür. Küresel salgından birçok ülke ekonomisi olumsuz etkilenmiştir. Buna ek olarak, salgının dış ticaret üzerinde de olumsuz etkisi olmuştur. Bu çalışmanın amacı Türkiye’nin ekonomik büyümesinde büyük itici gücü olan dış ticaretin, salgından nasıl etkilendiğinin analiz edilerek literatüre katkı sağlamaktır. Çalışmada Türkiye'nin 2013:01 ile 2020:11 dönemi ihracat ve ithalat verileri kullanılmıştır. Çalışmanın analizi iki bölümden oluşmaktadır. İlk olarak Bai ve Perron yapısal kırılma testi ile değişkenlerin kırılma tarihleri belirlenmiştir. İkinci olarak ise, bu kırılma tarihleri dikkate alınarak iki değişken için; trendde yapısal değişiklikler analizi yapılmıştır. Sonuç olarak; ihracat ve ithalat için 2020:2 tarihinde kırılma olduğu tespit edilmiştir. Yapısal değişiklik analizlerinde ise; salgının Türkiye’nin ihracat ve ithalat eğrilerinin eğimini değiştirdiği fakat ihracat ve ithalatın kısa sürede toparlandı̆̆ı görülmüştür.

Anahtar kelimeler:Covid-19, dış ticaret, uluslararası ticaret, yapısal kırılma Jel Kodu: I15, F10, F14

\section{The Impact Of The Covid-19 Outbreak On Turkey's Foreign Trade: A Structural Break Analysis}

\section{Abstract}

The Covid-19 virus, which emerged in Wuhan, China in December 2019, has turned into a global epidemic in 2020. The economies of many countries have been adversely affected by the global epidemic. In addition, the epidemic had a negative impact on foreign trade. The aim of this study is to contribute to the literature by analyzing how foreign trade, which is the major driving force in Turkey's economic growth, was affected by the epidemic. In the study, Turkey's export and import data for the period 2013:01 and 2020:11 were used. The analysis of the study consists of two parts. First, the breaking dates of the variables were determined by the Bai and Perron structural break test. Secondly, considering these breakout dates, for two variables; Structural changes in the trend analysis was performed. In conclusion; It was determined that there was a break in 2020:2 for exports and imports. In structural change analysis; It was seen that the epidemic changed the slope of Turkey's export and import curves, but exports and imports recovered in a short time.

Keywords: Covid-19, foreign trade, international trade, structural break Jel Codes: I15, F10, F14

\section{GİRİS}

Salgın hastalıklar tarihin çok eski dönemlerinden beri varolan bir olgudur. Tarihi kaynaklarda ilk salgın olarak M.Ö. 1200 civarında ortaya çıkmış olan Babil grip salgını görülmektedir. Günümüze kadar irili ufaklı 282 adet salgın yașanmıștır. Bu salgınlar arasında en fazla can kaybına neden olmuş olan (75-200 milyon kişi) 14. yy boyunca yaşanan ve Kara Ölüm (Black Death) olarak adlandırılan veba salgınıdır. Dünya tarihine bakıldığında ortalama olarak 100 yılda bir büyük salgınlar yaşandığı görülmektedir.

\section{Covid-19, SARS-COV-2 virüsünden} kaynaklanan bulaşıcı bir hastalıktır. İlk covid19 vakası Aralık 2019'da Çin'in Wuhan şehrinde görülmüştür. Daha sonrasında gerek Çin tarafından salgın hakkında dünya kamuoyuna geç bilgi verilmesi, gerek gelişen ulaşım imkanları vasıtasıyla salgın hızla dünyanın çeşitli bölgelerine yayılmıştır. Salgının yayılımını azaltmak için birçok ülke tarafından seyahat kısıtlamaları, sokağa çıkma

ATIF ÖNERİsí (APA): Ateş, E. (2021). Covid-19 Salgınının Türkiye'nin Dış Ticaretine Etkisi: Bir Yapısal Kırılma Analizi. İzmir İktisat Dergisi, 36(3), 617-627. Doi: 10.24988/ije.202136308

${ }^{1}$ Araştırma Görevlisi, Dokuz Eylül Üniversitesi, İktisadi ve İdari Bilimler Fakültesi, İzmir, EMAIL: erdem.ates@deu.edu.tr ORCID: 0000-0003-1459-9555 


\section{E. ATES}

yasakları vb. önlemler alınmıștır. Bu önlemler neticesinde, dünya genelinde ekonomik aktiviteler yavaşlamıştır.

Covid-19 salgını, hem bir sağlık krizi hem de bir ekonomik kriz ortaya çıkmasına neden olmuştur. Salgın bazı sektörleri olumsuz, bazı sektörleri ise olumlu etkilemiştir. Sanayi, iç ve dış ticaret, hava yolu, lojistik, turizm ve eğlence sektörleri olumsuz etkilenmişlerdir. E-ticaret, uzaktan eğitim, gıda, medikal ürünler, temizlik malzemesi, maske yapımı, film ve dizi sağlayan platformlar ve haberleşme sektörleri ise salgından olumlu etkilenmişlerdir. Salgın; sağlık harcamalarını artırmış, vergi gelirleri azalmış ve halka yapılan doğrudan gelir destekleri yoluyla devlet bütçelerine ek yükler getirmiștir.

Salgın, dünya ekonomisini hem arz hemde talep yönünden etkilemiştir. Salgın küresel tedarik zincirini durma noktasına getirmiş bu nedenle, birçok üretim kolu olumsuz etkilenmiştir. Üretimde yaşanan aksamalar ve geleceğe dair oluşan belirsizlikler işsizlik artışına ve firmaların nakit akıș dengelerinde bozulmalara neden olmuştur. İşsizlik artışları ve firma nakit akış dengelerinin bozulması ise, hem hane halkı hem de firma gelirinin azalmasina neden olmuştur. $\mathrm{Bu}$ etkiler birleşerek hammadde, ürün ve hizmet talebinin azalmasına neden olmuşlardır.

Arz ve talepte yaşanan sıkıntıları aşmak amacıyla küresel çapta genişletici para ve maliye politikaları uygulamaya konulmuştur. $\mathrm{Bu}$ kapsamda uygulanan genişletici politikalar; faiz oranlarının azaltılması, kredi destekleri verilmesi, doğrudan gelir desteği sağlanması, vergi tahsilatlarının ertelenmesi vb. olarak sayılabilir.

Salgının dıș ticaret üzerinde de olumsuz etkisi olmuştur. Bu etki; ülkeler arasındaki sınırların kapatılması, ihracat-ithalat yapan firmaların finansman sıkıntısı çekmeleri, tedarik zincirinde yaşanan aksamalar ve talep azalışları nedenleriyle oluştuğu söylenebilir. Ayrıca birçok ülke tıbbi ve tarımsal ürün ihracatını yasakladığı veya izne tabi tutmaya başlamıştır (Gruszczynski, 2020: 339). Mart 2020 itibariyle Fransa, Almanya, Türkiye ve ABD'nin ihracatı geçmiş yıl ortalamalarına göre sırasıyla; yüzde 38, 23, 25 ve 12 oranlarında azalmıştır (Demir ve Javorcik, 2020, s. 397). Mal ticaretinin azalmasi, tedarik zincirinde aksiliklerin yaşanması, sermaye akışının durması süreci geçici bir küreselleşmenin tersine dönmesi (deglobalization) olarak adlandırılmaktadır (Barua, 2020: 2).

Türkiye'de ilk covid-19 vakası 11 Mart 2020 tarihinde tespit edilmiştir. Covid-19 kaynaklı ilk ölüm ise, 17 Mart 2020 tarihinde gerçekleşmiştir. Bu gelişmeler üzerine 31 il özelinde 15 gün ulaşım yasağı, maskesiz dışarı çıkmama zorunluluğu, haftasonu sokağa çıkma yasağı gibi uygulamalar hayata geçirilmiştir. Salgının ekonomi üzerindeki etkilerini azaltabilmek için; Ekonomik istikrar kalkanı, kira desteği, ilave istihdam prim desteği ve işveren prim desteği gibi uygulamalar hayata geçirilmiştir.

Çalışmanın amacl; Covid-19 salgınının Türkiye'nin ihracat ve ithalatını nasıl etkilediği analiz etmektir. Literatür taraması sırasında, salgının Türkiye'nin ihracat ve ithalatı üzerindeki etkisinin analiz edildiği az sayıda çalışmaya rastlanmıştır. Çalışmanın bu açığı kapatması amaçlanmaktadır. Çalıșmanın ikinci bölümünde, konuyla ilgili literatür taraması yer almaktadır. Üçüncü bölümde, salgının dünya ve Türkiye'deki seyri ile dış ticaret üzerindeki etkisi incelenmiștir. Çalıșmanın dördüncü bölümde analiz hakkında bilgi verilmiş ve analiz sonuçları değerlendirilmiştir. Son bölümde ise, analiz sonuçlarına göre politika önerilerinde bulunulmuştur.

\section{LITERATÜR}

Çalışmanın bu kısmında salgının Türkiye ekonomisine olan etkilerini analiz eden çalışmalara yer verilmiştir.

Adıgüzel (2020) çalıșmasında, Mayıs 2020 itibariyle salgının Türkiye ekonomisine olan etkilerini analiz etmiştir. Çalışma kapsamında Türkiye'nin üretim, cari açık, istihdam, hanehalkı ve işletme gelirleri, ihracat, bütçe açığı ve merkezi yönetim toplam borç yükü 
verileri incelenmiştir. Sonuç olarak; incelenen değişkenlerde salgının olumsuz etkisi görülmüş ve salgının GSYH' de yaklaşık 400-675 milyar TL arası bir kayıp oluşturabileceği ön görülmüştür.

Soylu (2020) çalışmasında, Mayıs 2020 itibariyle salgının Türkiye ekonomisindeki etkilerini analiz etmiştir. Çalışma kapsamında Türkiye'nin turizm istatistikleri, dış ticaret istatistikleri, işgücü istatistikleri, büyüme rakamları, sektörel güven endeksleri ve sanayi üretim endeksleri üzerindeki etkileri incelenmiştir. Sonuç olarak; salgının etkilerini azaltmak için uygulanan genişletici para ve maliye politikalarının, salgının Türkiye ekonomisinde görülen olumsuz etkilerini atlatmasını sağlayacağı ön görülmüştür.

Demir ve Javorcik (2020) çalışmasında, salgının Türkiye ihracatındaki muhtemel etkisi finansman türleri üzerinden belirlemeye çalışmışlardır. Salgının etkisine en dirençli ödeme biçiminin, tarihsel ortalamaya göre akreditif ile yapılanlar olduğu görülmüștür. En fazla etkilenenler ise; ithalatçının ön ödemeli malların teslim edilmemesi riskini üstlendiği peşin nakit akışlarında yüzde 42'lik bir düşüş ve ihracatçının ödeme almama riskini üstlendiği açık hesap akışlarında yüzde 27'lik bir düşüş olduğunu göstermektedir.

Çetin (2020) çalışmasında, salgının Türkiye ekonomisi ve BIST-100 endeksi üzerindeki etkilerini analiz etmiştir. Çalışmada yöntem olarak en küçük kareler (EKK) kullanılmıştır. Çalışma dönemi olarak 21 Mart-24 Nisan 2020 dönemi alınmıştır. Çalışmada Borsa İstanbul BIST-100 endeksinin kapanış fiyatı (KF), en düşük fiyat (DF), en yüksek fiyat (YF) ve açılış fiyatı (AF), Türkiye'nin satın alma yöneticileri endeksi (PMI), sokağa çıkma kısıtlaması uygulanan günlerin sayısı (SY), yurt içi seyahat kısıtlaması uygulanan günlerin sayısı (YIS) ve yurt dışı seyahat kısıtlaması uygulanan günlerin sayısı (YDS), borç sözleşmesinde iyileștirmeye yönelik uygulama (PP), kamu harcamalarının tutarı (KH) ve COVID-19 yeni vakalarının sayısı (CS) değişkenler olarak kullanılmıştır. Sonuçta genel olarak; YS e YDS değişkenlerinin ekonomik aktivite ve BIST-100 endeksini olumsuz, diğer değişkenlerin ise olumlu etkilediği sonucuna varılmıştır.

Fernandes (2020) çalışmasında, salgının ekonomik etkilerini 30 ülke özelinden tahmin etmeye çalışmıştır. Türkiye için Nisan 2020 sonrasındaki 1,5 aylık tam kapanma yapıldığ üzerinden yapılan tahminlerde, GSYİH'nın yüzde 4,6 azalacağı tahmin edilmiştir. 2020 yılı için yapılan tahminde ise, Türkiye'nin GSYİH'sının yüzde 1,7 oranında azalacağı tahmin edilmiştir.

ULISA (2020) çalışmasında, salgının yayılımını azaltabilmek için uygulanan tedbirlerin sonucunda oluşan ekonomik yavaşlamanın etkisini incelemiştir. Analiz sonucunda, ekonomik faaliyetlerde yaşanacak yüzde 10'luk yavaşlamanın 30 günde yaklaşık 31,7 milyar tl lik bir GSYİH azalışına neden olacağ tahmin edilmiştir.

Demirhan (2020) çalışmasında, salgının CDS primleri ve BIST-100 endeksi üzerindeki etkisini incelemiştir. 7 Ocak 2020 tarihinde 281 civarlarında seyreden CDS primlerinin 31 Mart itibariyle yüzde 92,2 artarak 540,6 seviyesine yükseldiği, BIST 100 endeksinin ise değer kaybının aynı dönem için yüzde 20,4 seviyesinde olduğu belirlenmiştir.

Dündar (2020) çalışmasında, Türkiye'de görülen ilk covid-19 vakasının sonra geçen 3 haftada tüketim harcamalarının nasıl değiştiğini incelemiştir. Sonuç olarak; market ve alışveriş merkezlerinde yapılan harcamaların arttığı, konaklama, alkollü içecekler, araba kiralama, yemek, giyim gibi harcama kalemlerinde ise büyük azalışlar görülmüştür.

Peker ve Demirhan (2020) çalışmasında, salgının Borsa İstanbul üzerindeki etkisi sektörel olarak incelemiştir. Buna göre; salgının Çin'de başlamasından pozitif yönde etkilenip Türkiye'de başlamasından negatif yönde etkilenenler; Gıda (XGIDA), Tekstil (XTEKS), Orman, kağıt, basım (XKAGT), İnşaat (XINSA), Perakende ticaret, Lokanta ve oteller, Gayrimenkul yatırım ortaklıkları (XGMYO), 


\section{E. ATES}

Ulaștırma (XULAS), Banka (XBANK), Sigorta (XSGRT) ve Teknoloji (XUTEK) sektörleridir. Salgının Çin'de başlamasından etkilenmeyip Türkiye'deki gelişmelerden etkilenen sektörler ise Kimya (XKMYA), Metal ana sanayi (XMANA), Metal eşya (XMESY), Taş ve toprağa dayalı sanayi (XTAST), Toplan ticaret ve Spor (XSPOR)

sektörleridir. Salgının Çin'de başlamasından olumsuz yönde etkilenen sektörler ise Holdingler (XHOLD), Mali hizmetler (XUMAL) ve Finansal kiralama (XFINK) sektörleridir.

Çakmaklı ve dğr. (2020) çalışmasında, salgının Türkiye ekonomisine olası etkilerini incelemiştir. Çalışmada tam kapanma ve kısmi kapanma senaryoları ile modeller kurulmuştur. Sonuç olarak; tam bir kapanma uygulanması halinde Türkiye GSYİH'sının yüzde 4,5 oranında azalacağı tahmin edilmiştir.

Literatür taraması sırasında, salgının Türkiye'nin ihracat ve ithalatı üzerindeki etkisinin yapısal kırılma ve grafiksel olarak analiz edildiği bir çalışmaya rastlanmıştır. Çalışmanın bu açı̆̆ı kapatması amaçlanmaktadır.

\section{COVID-19 SALGINININ DÜNYADA VE TÜRKIYEDEKI SEYRİ VE DIS TİCARET ÜZERINNDEKİ ETKILLERİ}

Covid-19 salgınına ilişkin ilk vakalar Çin'in Wuhan şehrinde Aralık 2019 tarihinde görülmeye başlanmıştır. Hastalığın ilk kez dünya kamuoyuna aktarılması, Wuhan'da tanımlanamayan bir virüs tarafından enfekte olan insanlar olduğunun Çin'in Dünya Sağlık Örgütü bürosuna iletilmesi ile olmuştur. Daha sonra virüs bilim insanlarınca 13 Ocak 2020 tarihinde SARS-COV-2 adı ile tanımlanmıştır. 11 Mart 2020 tarihinde ise salgın, pandemi olarak tanımlanmıştır. Salgın dünya genelinde üretim, tüketim, küresel tedarik zinciri, dış ticaret ve turizm gibi alanları olumsuz etkilemiştir. Salgının çıkış yeri olan Çin'in dünya imalatının yüzde 65'ini, dünya imalat sanayi ihracatının ise yüzde 41'ini gerçekleştirdiği düşünüldügünde salgının dünya ticaretindeki etkisi daha iyi anlaşılabilir. Salgın tedarik zincirinde büyük aksamalara neden olmuştur. Salgının Çin'i en çok etkilediği Ocak ve Şubat 2020 tarihlerinde 350 bin konteynırlık mal ihraç edilememiş ve Çin limanlarından yapılan deniz taşımacılığı yüzde 49 azalmıştır (Mauro, 2020: 32). Bu nedenle bazı firmaların üretimlerini Çin'den diğer ülkelere taşıma kararı aldıkları açıklanmıştır. $\mathrm{Bu}$ firmalara örnek olarak; Mazda, Google, Microsoft, Daikin, Komatsu firmaları verilebilir (Barua, 2020: 22). Şekil 1'de dünya ticaret hacminin 2013:01-2020:11 aralığındaki aylık seyri görülmektedir. Covid-19 etkisinin özellikle Nisan ve Mayıs 2020 döneminde görüldüğü, daha sonrasında ise "V" şeklinde toparlanarak eski düzeylerine yaklaştığı görülmektedir.

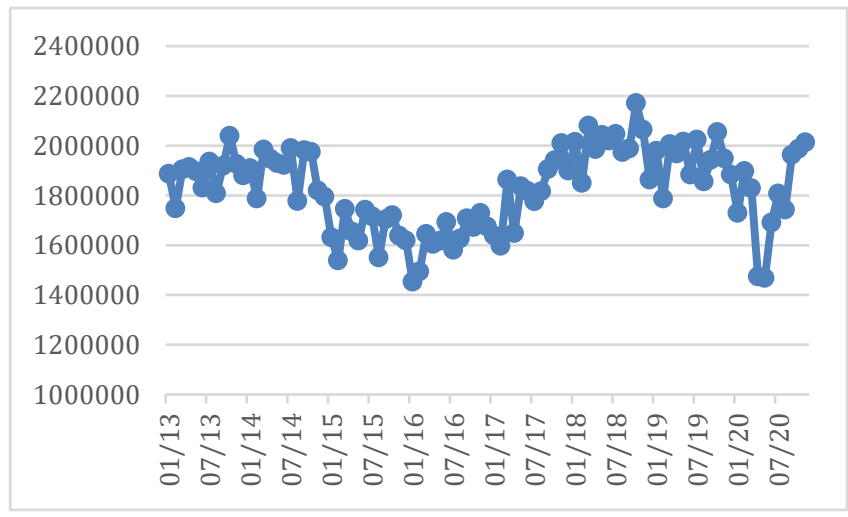

Şekil 1: Dünya Ticaret Hacmi (2013:012020:11)

Tablo 1 için 2013-2019 dönemini için dünya ticaret hacimlerinin aylı ortalamaları hesaplanmıştır. Salgının dünya ticaret hacmini, dönem ortalamasından ne kadar saptırdığ görülmeye çalışılmıştır. Tabloya göre Mart ile Ağustos 2020 ayları dahil olmak üzere Dünya ticaret hacmi, ortalamasının altında kalmıştır. Özellikle Nisan ayında yüzde 18,9 ve Mayıs ayında yüzde 20,69'lük büyük sapmalar görülmüştür. $\mathrm{Bu}$ sapmaların sadece salgının neden olduğu arz ve talep şoklarına bağlı olmadığı ayrıca bir çok ülkenin özellikle gıda ve medikal ürünlere ek tarife, kota gibi önlemler uygulamasının etkili olduğu düşünülmektedir. Salgın dolayısıyla Dünya Ticaret Örgütü üyesi ülkeler 109 adet ticareti kısıtlayıcı tedbir uygulamışlardır (Kumari ve Bharti, 2020: 3). 
Tablo 1: Dünya Ticaret Hacmindeki Azalış (2020-\%)

\begin{tabular}{|c|c|c|c|c|c|c|c|c|c|c|}
\hline Ocak & Şubat & Mart & Nisan & Mayls & Haziran & Temmuz & Ağustos & Eylül & Ekim & Kasım \\
\hline$-3,25$ & 12,56 & $-3,20$ & $-18,90$ & $-20,69$ & $-8,30$ & $-3,19$ & $-1,70$ & 4,51 & 2,48 & 7,28 \\
\hline
\end{tabular}

Türkiye'deki ilk covid-19 vakası 10 Mart 2020, covid-19 kaynaklı ilk ölüm ise 17 Mart 2020 tarihinde görülmüştür. Sonrasında salgının yayılımını yavaşlatmak adına birçok önlem alınmıştır. Bunlardan bazıları;

- 12 Mart 2020'de ilköğretim, lise ve üniversitelerde eğitim ve öğretime ara verildi ve uzaktan eğitime geçilmiştir.

- 22 Mart 2020'de 65 yaş üstü ve kronik hastalığı olan vatandaşlara sokağa çıkma kısıtlaması getirilmiştir.

- 3 Nisan 2020'de 20 yaş altı vatandaşlara sokağa çıkma kısıtlaması getirilmiştir.

- Haziran 2020'de 18 yaş altı olarak yaş aralığı genişletilmiştir.

- 11 Nisan 2020 tarihinde 30 büyükşehir ve Zonguldak'ta haftasonları sokağa çıkma kısıtlaması uygulamasına bașlanmıș, bu uygulama kapsamındaki illerin kapsamı değiștirilerek 6 Haziran
2020 tarihine kadar uygulamaya devam edilmiştir.

- 4 Mayıs 2020 tarihinde Cumhurbaşkanı Recep Tayyip Erdoğan tarafından normalleşme adımları açıklanmış ve kısıtlamalar kademeli olarak azaltılmaya bașlanmıștır (Budak ve Korkmaz, 2020: 73).

- Vaka sayılarında görülen artışa bağlı olarak, 20 Kasım 2020 tarihinde Sağlık Bakanı Fahrettin Koca tarafından 65 yaş üstü ve 20 yaş altı kişilere sokağa çıkma kısıtlaması getirildiğini açıklanmıștır. Buna ek olarak 21 Kasım 2020 tarihinden itibaren önceden kaldırılmış olan haftasonu sokağa çıkma yasağı tekrar uygulamaya konulmuştur.

- 13 Ocak 2021 tarihinde Çin menşeili Coronavac aşısı Türkiye'de uygulanmaya başlanmıştır.

Tablo 2'de Türkiye'nin salgın sürecinde aldığı dış ticarete yönelik tedbirler görülmektedir. Tabloya göre alınan altı önlemin beş tanesi ticareti kısitlayıcı niteliktedir. Alınan önlemlerin beş tanesinin medikal ürünleri hakkında olduğu, bir tanesinin ise tarım ürünü ile ilgili olduğu görülmektedir.

Tablo 2: Türkiye'nin Salgın Sürecinde Aldığg Dış Ticaret Önlemleri

\begin{tabular}{|c|c|c|c|c|c|}
\hline Uygulama & Etkilenen Ürünler ve Uygulama Türü & Etkisi & Etkilenenler & $\begin{array}{l}\text { Başlangıç } \\
\text { tarihi }\end{array}$ & Bitiș tarihi \\
\hline $\begin{array}{l}\text { İhracat için lisans veya izin } \\
\text { gereksinimi }\end{array}$ & $\begin{array}{l}\text { Maske ve kişisel } \\
\text { koruyucu ekipman ihracatını düzenlenmesi. }\end{array}$ & Kisıtlayıcı & Tüm ülkeler & 4.03.2020 & 1 \\
\hline $\begin{array}{l}\text { İhracat için lisans veya izin } \\
\text { gereksinimi }\end{array}$ & $\begin{array}{l}\text { Kolonya, etil alkol, dezenfektan ve hidrojen } \\
\text { peroksit ile ilgili ihracat kısıtlamaları. }\end{array}$ & Kısıtlayıcı & Tüm ülkeler & 18.03.2020 & 2.05 .2020 \\
\hline Tarife indirimi & $\begin{array}{l}\text { Etil alkol, tek kullanımlık tıbbi maske ve } \\
\text { tıbbi vantilatörler için ithalat vergilerinin } \\
\text { kaldırılması. (15 Eylül 2020: Etil alkol ithalat } \\
\text { vergilerinin kaldırılmasına son verildi.) }\end{array}$ & Serbestleștirme & Tüm ülkeler & 25.03 .2020 & 1 \\
\hline $\begin{array}{l}\text { İhracat için lisans veya izin } \\
\text { gereksinimi }\end{array}$ & $\begin{array}{l}\text { Ventilatörler ve diğer COVID } \\
\text { tıbbi ekipmanlarına ilişkin ihracat kısıtlamaları }\end{array}$ & Kisıtlayıcı & Tüm ülkeler & 26.03 .2020 & 2.05 .2020 \\
\hline Sertifika gereksinimi & $\begin{array}{l}\text { Test kitleri için sertifika ile ithalat yetkisinin } \\
\text { sağlanması }\end{array}$ & Kisıtlayıcı & Tüm ülkeler & 2.04 .2020 & 1 \\
\hline $\begin{array}{l}\text { İhracat için lisans veya izin } \\
\text { gereksinimi }\end{array}$ & Limonlar için kota uygulaması & Kısıtlayıcı & Tüm ülkeler & 7.04 .2020 & 7.08 .2020 \\
\hline
\end{tabular}

Şekil 2'de Türkiye'nin ihracat ve ithalatının 2013:01-2020:11 aralığındaki aylık seyri görülmektedir. Covid-19 etkisinin özellikle Nisan ve Mayıs 2020 döneminde görüldüğü daha sonrasında ise "V" şeklinde toparlanarak eski düzeylerine yaklaştıkları görülmektedir. 


\section{E. ATES}

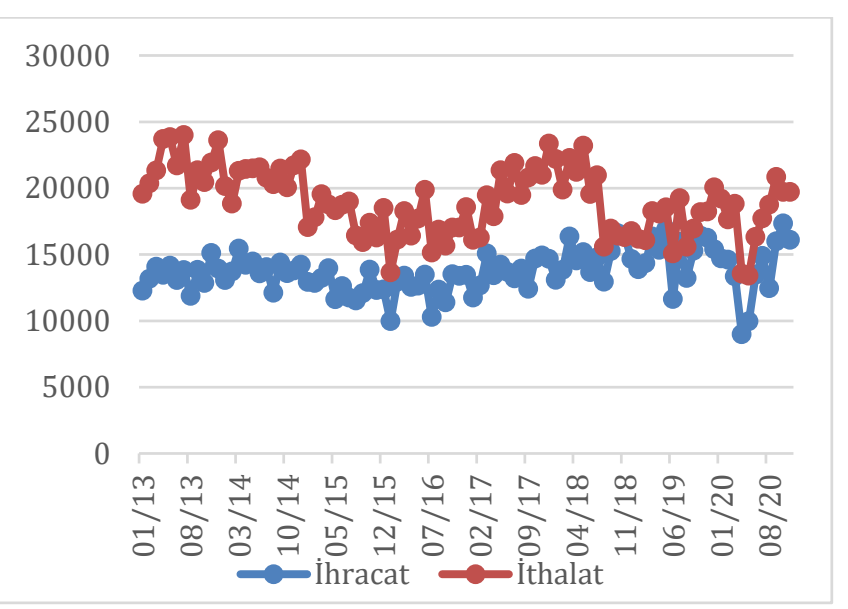

Şekil 2: Türkiye'nin İhracat ve İthalatı (2013:01-2020:11)

Tablo 3 için 2013-2019 döneminde Türkiye'nin aylık ihracat ve ithalat ortalamaları hesaplanmıştır. Salgının Türkiye'nin ihracat ve ithalatını, dönem ortalamasından ne kadar saptırdığı görülmeye çalışılmıştır. Tabloya göre ihracatta; Mart ile Mayıs 2020 ayları dahil olmak üzere Türkiye'nin ihracatının, ortalama ihracatının altında kaldığı görülmüștür. Özellikle Nisan ayında yüzde 35,55 ve Mayıs ayında yüzde 29,73'lük büyük sapmalar görülmüștür. İthalatta ise; Şubat ile Temmuz ayları dahil olmak üzere Türkiye'nin ithalatının, ortalama ithalatının altında kaldığ görülmüștür. Özellikle Nisan ayında yüzde 30,96 ve Mayıs ayında yüzde 35,10'lük büyük sapmalar görülmüștür.

Tablo 3: Türkiye'nin İhracat ve İthalatında Salgının Etkisi (2020- \%)

\begin{tabular}{|l|c|c|}
\hline $\mathbf{2 0 2 0}$ & İhracat & İthalat \\
\hline Ocak & 18,33 & 7,70 \\
\hline Şubat & 9,31 & $-1,47$ \\
\hline Mart & $-10,09$ & $-6,18$ \\
\hline Nisan & $-35,55$ & $-30,96$ \\
\hline Mayıs & $-29,73$ & $-35,10$ \\
\hline Haziran & 2,70 & $-16,07$ \\
\hline Temmuz & 11,07 & $-12,04$ \\
\hline Ağustos & $-0,88$ & 6,43 \\
\hline Eylül & 18,34 & 13,05 \\
\hline Ekim & 19,60 & 5,18 \\
\hline Kasım & 10,32 & 4,16 \\
\hline
\end{tabular}

Salgının dış ticaret üzerinde derin olumsuz etki oluşturmasının nedeni olarak, küreselleşme ve bunun üretimdeki yansıması olan küresel değer zinciri gösterilebilir. Küresel değer zincirine katılımı yüksek olan ülkeler, salgından daha yüksek oranda etkilenmişlerdir (Espitia, Mattoo, Rocha, ve Ruta, 2021: 5). Salgının hem Dünya ticaretinde hem de Türkiye'nin diş ticaretinde sektörel anlamda eșit olmayan bir etki yaptığı düşünülmektedir (Susskind ve Vines, 2020: 5). Salgından imalat sanayi, diş ticaret, hava yolu, lojistik, turizm, mücevherat, konaklama ve eğlence sektörleri olumsuz etkilenmiştir. E-ticaret, uzaktan eğitim, gıda, medikal ürünler, temizlik malzemeleri, maske yapımı, film ve dizi sağlayan platformlar ve haberleşme sektörleri ise olumlu etkilenmiştir. Salgının etkilerinin giderilmesinin de eşit olmayacağı ön görülebilir. Salgından sonra imalat sanayi, dış ticaret gibi alanların grafiğinin "V" ya da "U" şeklinde düzeleceği tahmin edilirken; turizm, konaklama ve eğlence başta olmak üzere hizmetler sektörünün grafiğinin "L" şeklinde olacağı yani kısa dönemde toparlanamayacağı tahmin edilmektedir (Mann, 2020: 82).

Tablo 4'te çeşitli uluslararası kuruluşların Türkiye için yapmış oldukları büyüme tahminleri görülmektedir (Jackson, Weiss, Schwarzenberg, ve Nelson, 2020: 22). Tahminlere göre; Türkiye ekonomisi 2020 yılında yüzde 2,9 ile yüzde 5 aralığında küçülecektir. 2021 yılında ise en az 2020 küçülmesi kadar bir ekonomik büyüme gerçekleşeceği tahmin edilmektedir.

Tablo 4: Türkiye İçin Büyüme Tahminleri (\%)

\begin{tabular}{|c|c|c|}
\hline \multirow{3}{*}{ OECD } & 2019 & 0,9 \\
\cline { 2 - 3 } & 2020 & $-2,9$ \\
\cline { 2 - 3 } & 2021 & 3,9 \\
\hline \multirow{3}{*}{$\begin{array}{c}\text { Dünya } \\
\text { Bankası }\end{array}$} & 2019 & 0,9 \\
\cline { 2 - 3 } & 2020 & $-3,8$ \\
\hline \multirow{3}{*}{ IMF } & 2021 & 5 \\
\cline { 2 - 3 } & 2019 & 0,9 \\
\cline { 2 - 3 } & 2020 & -5 \\
\hline
\end{tabular}

\section{VERİ, YÖNTEM VE ANALİZ}

Covid-19 salgının ekonomik etkileri daha önce yaşanan 1929, 2008 küresel ekonomik krizlerinden ve SARS, MERS, Ebola vb. salgın hastalıklar nedeniyle oluşan ekonomik olumsuzluklarla kıyaslanamayacak düzeydedir. Bunun nedenleri olarak; covid-19 salgınının, 
küreselleșmenin etkisiyle bir pandemi haline dönüşmesi, dünyanın eski dönemlere oranla fazlasıyla bütünleşmiş olması ve salgının etkisinin küresel değer zinciri kanalıyla yayılma etkisi göstermiş olması sayılabilir.

Çalışmanın amacı salgının Türkiye'nin dış ticaretinde oluşturduğu etkileri analiz etmektir. Bu nedenle Türkiye'nin ihracat ve ithalat rakamlarında salgın sonrasında nasıl bir değişim olduğu görülmeye çalışılmıştır. Bunun için ilk olarak, Bai ve Perron'un çoklu yapısal kırılma testi uygulanmıştır. $\mathrm{Bu}$ testin uygulanmasının nedeni, testin yapısal kırılma tarihlerini belirlemesidir. Daha sonrasinda ise Türkiye'nin aylık ihracat ve ithalat rakamları üzerinde grafiksel bir analiz yapılmıștır. Veriler Dünya Ticaret Örgütü'nün internet sitesinden nominal olarak milyon ABD doları cinsinden alınmıştır. Veriler analizde doğal logaritmaları alınarak kullanılmıştır. Dönem itibariyle 2013:01 ile 2020:11 aralığ incelenmiștir. İnceleme döneminin uzun tutulmasının nedeni, 2015 Rus savaş uçağının düşürülmesi, 2016 darbe girișimi, 2018'de ABD ile yaşanan Rahip Brunson krizlerinin Türkiye'nin dış ticareti üzerindeki etkisi ile 2020 covid-19 salgınının etkisinin kıyaslanmak istenmesidir.
Calıșmada Bai ve Perron yapısal kırılma testi kullanılmıştır. Bai ve Perron (1998) çalışmalarında en küçük kareler yöntemi ile tahmin edilen doğrusal bir modelde yapısal kırılma olduğu durumu incelemişlerdir. oluşturmuşlardır (Yıldırım, 2011: 33). Çalışmanın ampirik uygulamasında Bai ve Perron (2003) yöntemi ortaya konulmuştur. Uygulama sırasında "none" yöntemi seçilmiştir. Eviews programıla yapılan Bai ve Perron testlerinin beş kırılmaya kadar izin verdiği görülmüştür. Fakat analiz döneminin uzunluğu dikkate alındığından bunun yetersiz kalacağı düşünülerek R programı ile daha yüksek sayıda kırılmaya ulaşılmıştır. Bai ve Perron (1998, 2003) çalışmalarında (i) kırılma tarihinin tahmini, (ii) verinin yapısı ve kırılmalı modeldeki hata terimine ilişkin çeşitli hipotezler altında kırılma tarihlerine ilişkin güven aralıklarının oluşturulması, (iii) kırılmalar arasında veri ile artık terimler için farklı dağılımlar ve artık terimler için farklı otokorelasyonlar olabileceği göz önüne alınarak testlerin oluşturulması, (iv) kırılma sayısının tahmini konularını detaylı olarak incelemişlerdir.

Tablo 5: İhracat İçin Yapısal Değişim Sayısının Belirlenmesi İçin Kullanılan Testlere İlişkin Sonuçlar

\begin{tabular}{|c|c|c|c|}
\hline Kırılmalar & $\begin{array}{c}\text { Ölçeklendirilmiş } \\
\text { F- istatistiği }\end{array}$ & $\begin{array}{c}\text { Ă̆ırlıklıklı } \\
\text { F- istatistiği }\end{array}$ & Kritik Değer \\
\hline $1^{*}$ & 19,16999 & 19,16999 & 9,63 \\
\hline $2^{*}$ & 16,05623 & 17,61065 & 8,78 \\
\hline $3^{*}$ & 19,07543 & 23,40082 & 7,85 \\
\hline $\mathbf{4}^{*}$ & $\mathbf{1 9 , 1 5 0 1 5}$ & $\mathbf{2 5 , 5 7 7 8}$ & $\mathbf{7 , 2 1}$ \\
\hline $6^{*}$ & 17,27946 & 24,87313 & 6,69 \\
\hline $7^{*}$ & 14,9496 & 23,10829 & 6,23 \\
\hline $8^{*}$ & 13,37294 & 21,97636 & 5,86 \\
\hline $9^{*}$ UDMax istatistiği* & 19,16999 & 21,28805 & 5,51 \\
\hline \multicolumn{2}{|c|}{ WDMax istatistiği* 25,57780} & 20,47901 & 5,2 \\
\hline \multirow{2}{*}{ U\%5 anlamlılık seviyesinde anlamlıdır. } \\
**Bai ve Perron, 2003 kritik değerleri alınmıștır.
\end{tabular}

Tablo 5'te Türkiye'nin ihracatı için yapılmıș olan Bai ve Perron test sonuçları görülmektedir. Bilgi kriterlerine göre düzeyde ve trendde 4 kırılma olduğu görülmüştür. Bu kırılmalar, 2013(10), 2016(9), 2019(5), 2020(2) tarihlerinde gerçekleşmiştir. Buradan Türkiye'nin ihracatında covid-19 salgınının Şubat 2020 tarihinde kırılmaya neden olduğu 


\section{E. ATES}

söylenebilir. Tablo 6'da ise ihracatta belirlenen kırılma tarihleri yer almaktadır. Şekil 3'te ise, ihracat serisindeki yapısal kırılma tarihlerini gösteren grafik görülmektedir. Kırılma tarihlerine bakıldığında bu tarihlerde ihracatı etkileyecek önemli olayların yaşandığ düşünülebilir. Covid-19 salgınının ihracatta neden olduğu şokun boyutlarını grafikten elde edilen düzey değerlerinden görmek mümkündür. Şubat 2020'de olușan kırılma sonucunda oluşan ihracat ortalamasının $(1,754)$ incelenen dönemin en düşük düzeyinde olduğu görülmüştür. Trend verilerine bakıldığında ise covid-19 salgını sonrasında ihracatın hızla toparlandığı trend değerinin $(0,026)$ incelenen dönemin en yüksek değeri olmasından görülebilmektedir. Buradan ihracatın "V" şeklinde toparlandığı söylenebilir.

Tablo 6: Tahmin Edilen Kırılma Tarihleri

\begin{tabular}{|c|c|c|}
\hline Güven Aralı̆̆ & Düzey Değeri & Trend \\
\hline $2013(1)-2013(10)$ & 4,122726 & $-0,000234709$ \\
\hline $2013(11)-2016(9)$ & 4,186727 & $-0,002655188$ \\
\hline $2016(10)-2019(5)$ & 3,995954 & 0,002581731 \\
\hline $2019(6)-2020(2)$ & 3,559568 & 0,007427074 \\
\hline $2020(3)-2020(11)$ & 1,754643 & 0,026042794 \\
\hline
\end{tabular}

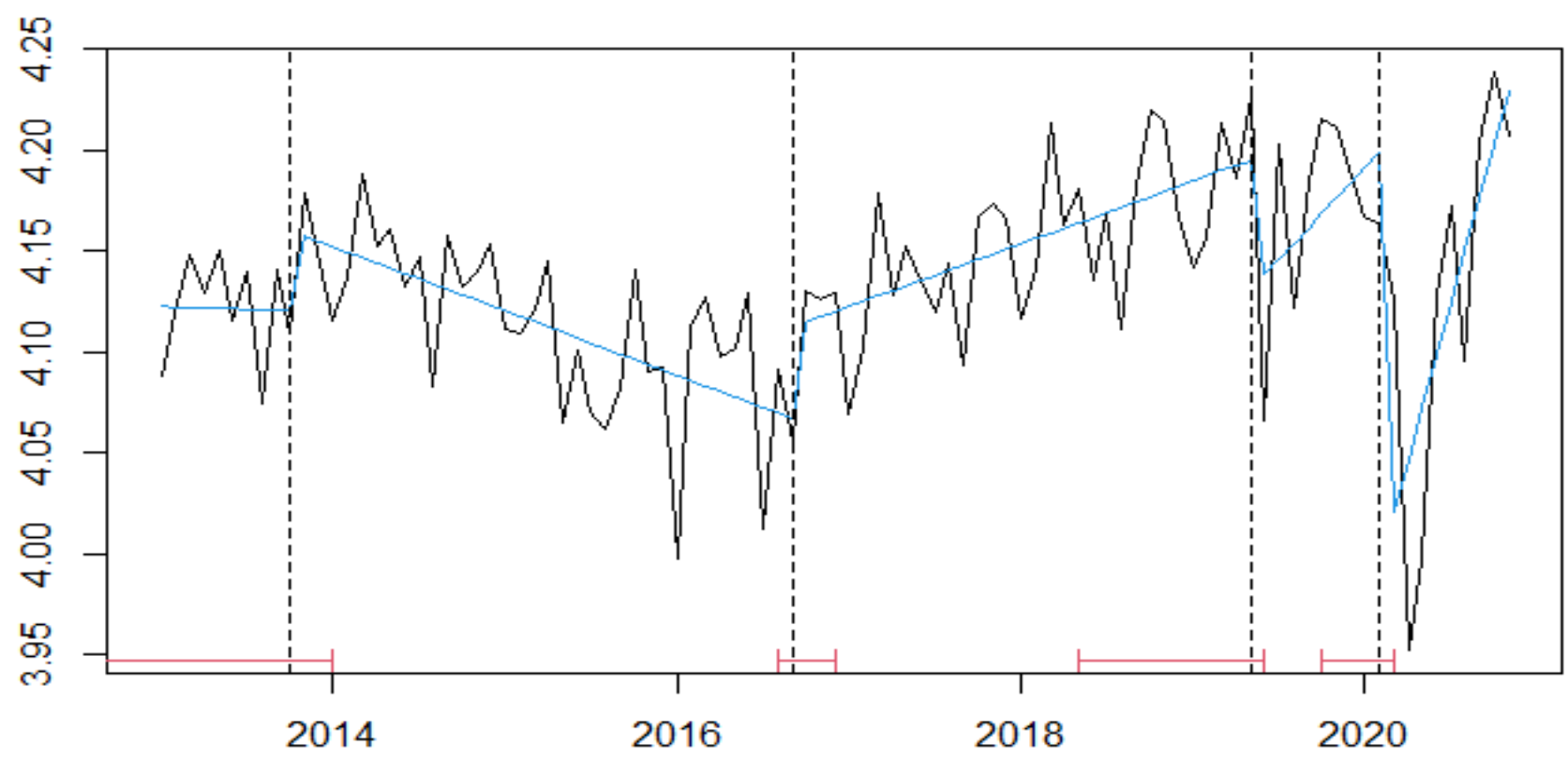

Şekil 3: İhracat Serisindeki Yapısal Değişim Tarihleri

Tablo 7'de Türkiye'nin ithalatı için yapılmış olan Bai ve Perron test sonuçları görülmektedir. Bilgi kriterlerine göre düzeyde ve trendde 3 kırılma olduğu görülmüștür. $\mathrm{Bu}$ kirılmalar 2017(2), 2018(7), 2020(2) tarihlerinde gerçekleşmiştir. Buradan Türkiye'nin ithalatında covid-19 salgınının Şubat 2020 tarihinde kırılmaya neden olduğu söylenebilir. Tablo 8'de ise ithalatta belirlenen kırılma tarihleri yer almaktadır. Şekil 4'te ise, ithalat serisindeki yapısal kırılma tarihlerini gösteren grafik görülmektedir. Kırılma tarihlerine bakıldığında bu tarihlerde ithalatı etkileyecek önemli olayların yaşandığı düşünülebilir. Covid-19 salgınının ithalatta neden olduğu şokun boyutlarını grafikten elde edilen düzey değerlerinden görmek mümkündür. Şubat 2020'de oluşan kırılma sonucunda oluşan ithalat ortalamasının $(2,705)$ incelenen dönemin en düşük düzeyinde olduğu görülmüştür. Trend verilerine bakıldığında ise covid-19 salgını sonrasında ithalatın hızla toparlandığ dönemin en yüksek değeri $(0,016)$ olmasından anlaşılabilmektedir. Buradan ithalatın "V" şeklinde toparlandığı söylenebilir. 
Tablo 7: İthalat İçin Yapısal Değişim Sayısının Belirlenmesi İçin Kullanılan Testlere İlişkin Sonuçlar

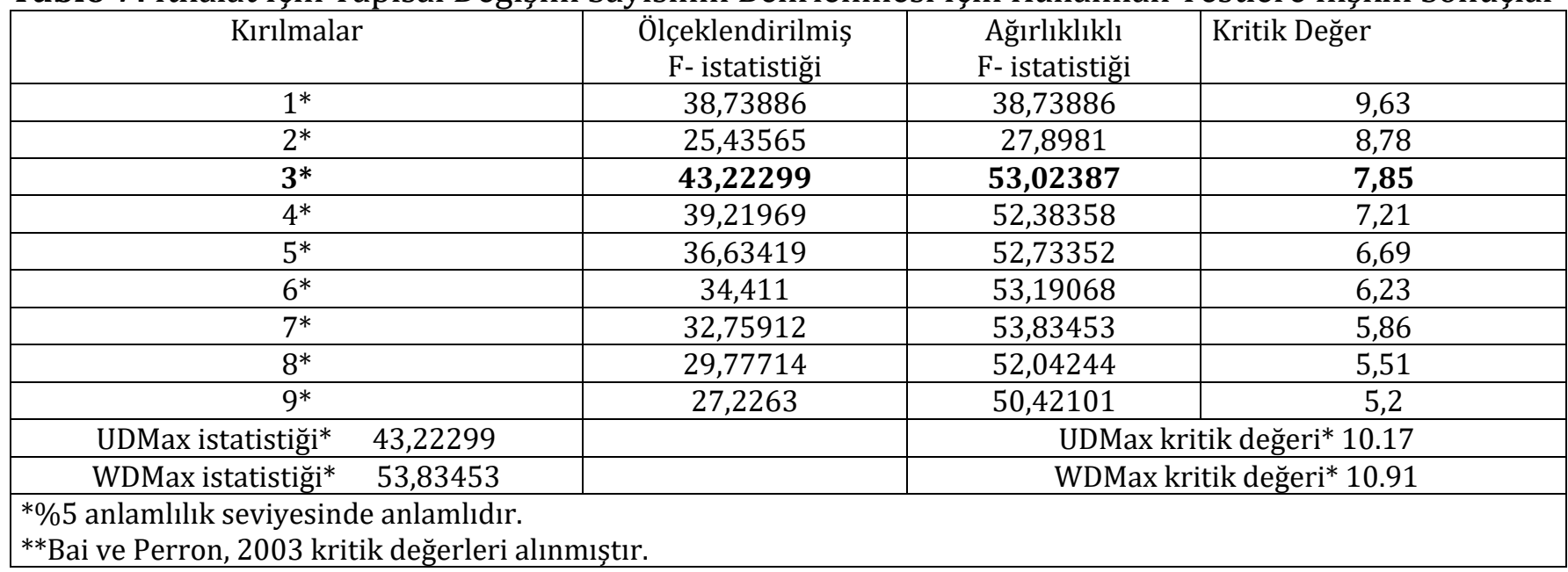

Tablo 8: Tahmin Edilen Kırılma Tarihleri

\begin{tabular}{|c|c|c|}
\hline Güven Aralı̆̆ & Düzey Değeri & Trend \\
\hline $2013(1)-2017(2)$ & 4,357578 & $-0,003055721$ \\
\hline $2017(3)-2018(7)$ & 4,164829 & 0,002620698 \\
\hline $2018(8)-2020(2)$ & 3,965265 & 0,003532169 \\
\hline $2020(3)-2020(11)$ & 2,705815 & 0,016876826 \\
\hline
\end{tabular}

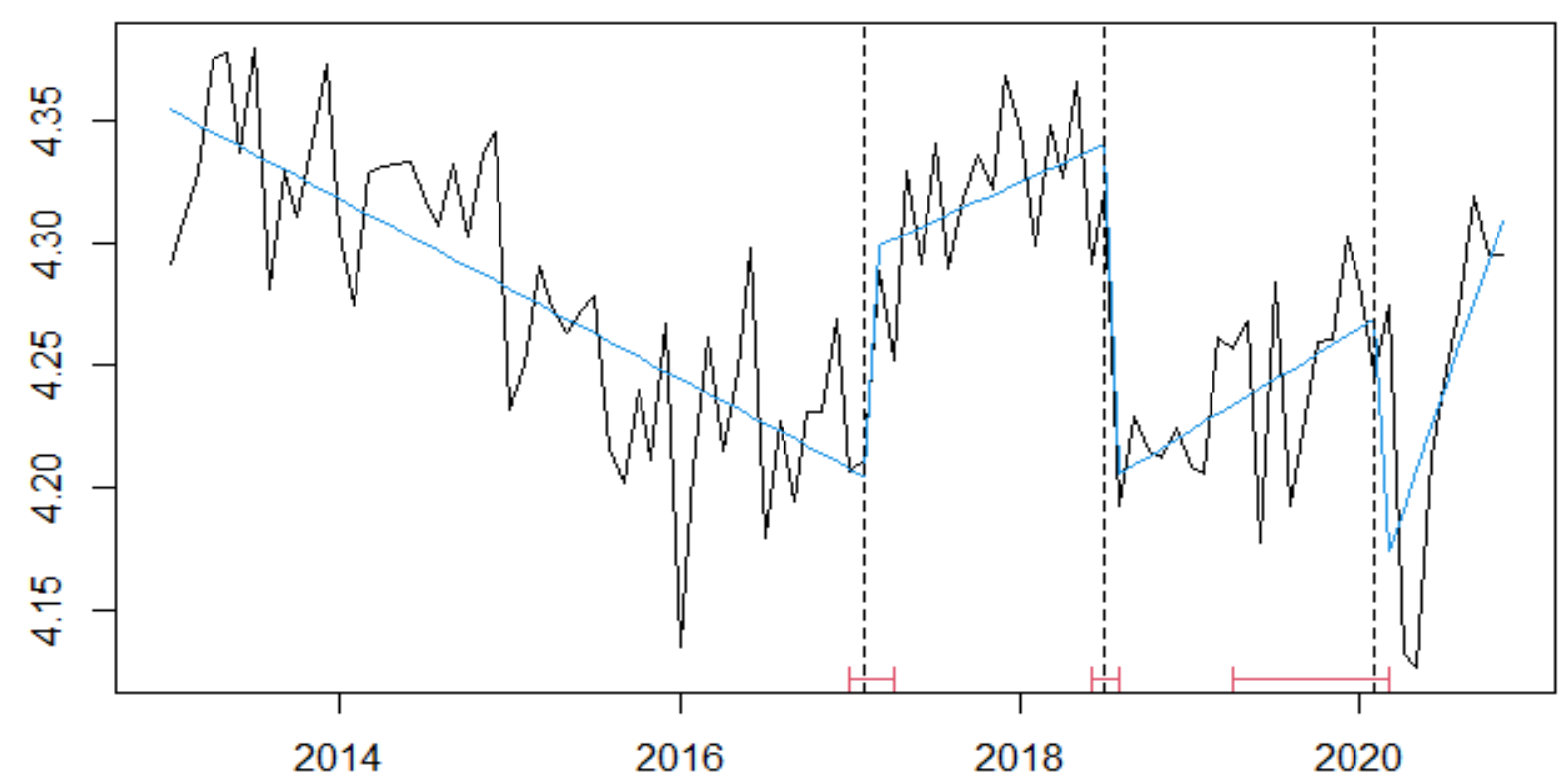

Şekil 4: İthalat Serisindeki Yapısal Değișim Tarihleri

\section{SONUÇ}

Covid-19 salgını dünya tarihinde eşine az rastlanan bir olaydır. Dünya tarihinde daha önce birçok salgın görülmesine rağmen, modern dönemde yaşanan en büyük salgın olduğu söylenebilir. Salgının hızlı yayılmasının nedeni olarak, ulaşım imkanlarının artmış olması yani küreselleşme gösterilmektedir. Salgın eğitimden sağlığa, insan ilişkilerinden ekonomiye kadar hayatın hemen hemen tüm alanlarını etkilemiştir.

Salgının yayılım hızını azaltmak için alınan sokağa çıkma ve ulașım yasakları, karantina uygulamaları gibi önlemler ile ekonomik faaliyetlerde sınırlanmıştır. Üretim azalışları tedarik zincirini sekteye uğratarak bir arz; tüketim azalışları ise bir talep şoku yaratmıştır. Salgının ekonomik etkileri o kadar büyük olmuştur ki, 2008 küresel krizinin etkisini 


\section{E. ATES}

aşmış kimi uzmanlara göre bu tip bir krizi ancak 2. Dünya Savaşı döneminde yaşanan ekonomik etkilerle kıyaslamak doğru olacaktır.

Çalışmada salgının Türkiye'nin ihracat ve ithalatı üzerindeki etkisi görülmeye çalışılmıştır. Buna göre, salgının hem ihracat hem de ithalatta Şubat 2020 tarihinde kırılmaya neden olduğu görülmüştür. Daha sonrasında ise kısmi normalleşme ile beraber hem ihracat hem de ithalatın "V" şeklinde diye tabir edilebilecek şekilde toparlandığı ve hızla salgın öncesi seviyelerine ulaștığı görülmüștür. Salgının ihracat ve ithalat üzerindeki etkisinin arz, talep şoklarına ek olarak dünya genelinde ticareti kısıtlayıcı önlemlerin alınması nedeniyle ortaya çıktığı düşünülmektedir.

Salgının uzun dönemde küresel ticaret üzerinde farklı etkileri ortaya çıkabilir. Birincisi; salgın sırasında yaşanan arz şoku nedeniyle ülkeler küresel değer zincirine olan bağımlılıklarını sorgulayabilirler ve mümkün olduğunca üretimlerini ülke içerisinde gerçekleştirme yoluna gidebilirler. Bu durum ise karşılaştırmalı üstünlükler teorisine aykırı bir etki yaratarak dünya refahının azalmasına yol açabilir. İkincisi; salgının etkisiyle ülkeler olağanüstü durumlardan daha az etkilenmek için dış ticaret politikalarını daha korumacı hale getirebilirler. Bu ise dünya ticaret hacmini azaltıcı bir etki yapabilir ve dünya ticaretinde bir paradigma değişikliğine neden olabilir. Üçüncüsü ise, ülkeler salgın gibi küresel bir olayın ancak uluslararası dayanışma ile aşılabilecek bir durum olduğunu düşünerek, dünya ticaretini serbestleştirme yönünde daha cesur adımlar atabilirler.
Salgın sonrasında dünya ekonomisinin yeniden yapılanması sorunu ortaya çıkacaktır. Bunun sağlıklı bir şekilde olabilmesi için, IMF, Dünya Bankası, Dünya Ticaret Örgütü gibi uluslararası kuruluşların yönlendirmeleri çok önemli olacaktır. Ayrıca ABD ve Çin gibi ülkelerinde bu sürece dahil olmaları salgın sonrası dünya ekonomisinin hızla toparlanmasına yardım etme potansiyeli bulunmaktadır. ABD'nin genişletici para politikaları uygulayarak dünya piyasalarını desteklemesi, Çin'in ise özellikle Bir Kuşak Bir Yol (OBOR) girişimi kapsamında borçlanmış olan ülkelerin borçlarını ertelemesi olumlu sonuçlar doğurabilir.

Salgın sonrasında bazı sektörlerin hızla, bazı sektörlerin ise yavaș bir șekilde toparlanacağı ön görülmektedir. Örneğin; imalat sanayinin "V" şeklinde toparlanacağı fakat hizmetler sektörünün "L" şeklinde uzun bir süre salgının etkisinden kurtulamayacağı ön görülmektedir. Türkiye için turizm gelirlerinin önemli olduğu düşünüldüğünde, hizmetler sektöründe görülecek bu etkinin Türkiye ekonomisini olumsuz etkileyeceği söylenebilir. Bu olumsuz etkiyi azaltmak için Türkiye'nin doğrudan gelir desteklerinin artırılması, bazı vergi erteleme ve muafiyetlerinin sağlanması vb. bazı ekonomik tedbirler alması gerektiği düşünülmektedir.

Salgının dış ticaret anlamında bazı fırsatlar yaratacağı söylenebilir. Salgın sırasında tedarik zincirinde sıkıntıları yaşanmıştır. Tedarik zincirinin çeşitlendirilmesinin önemi böylece ortaya çıkmıştır. Türkiye, Avrupa kıtasına yakın konumunun avantajını da kullanarak, küresel değer zincirinden daha yüksek paylar alabilmesini sağlayacak politikaları geliştirmelidir.

\section{KAYNAKÇA}

Adıgüzel, M. (2020). Covid-19 Pandemisinin Türkiye Ekonomisine Etkilerinin Makroekonomik Analizi. İstanbul Ticaret Üniversitesi Sosyal Bilimler Dergisi, 19(37) Bahar (Özel Ek), 191-221.

Bai, J. and P. Perron (1998), "Estimating and Testing Linear Models with Multiple Structural Changes", Econometrica, (66), 47-78.
Bai, J. and P. Perron (2003), "Computation and Analysis of Multiple Structural Change Models", Journal of Applied Econometrics, (18), 1-22.

Barua, S. (2020). COVID-19 pandemic and world trade: Some analytical notes. SSRN Electronic Journal, 1-35.

Budak, F., \& Korkmaz, Ş. (2020). COVID-19 Pandemi Sürecine Yönelik Genel Bir 
Değerlendirme: Türkiye Örneği. Sosyal Araştırmalar ve Yönetim Dergisi, 1, 62-79.

Çakmaklı, C., Demiralp, S., Özcan, Ş. K., Yeşiltaş, S., \& Ylldırım, M. A. (2020). COVID-19 and Emerging Markets: The Case of Turkey. İstanbul: Koç Üniversitesi-TUSIAD Economic Research Forum.

Çetin, A. C. (2020). Koronavirüs (Covid-19) Salgınının Türkiye'de Genel Ekonomik Faaliyetlere ve Hisse Senedi Borsa Endeksine Etkisi. Mehmet Akif Ersoy Üniversitesi Uygulamalı Bilimler Dergisi, 4(2), 341-362.

Demir, B., \& Javorcik, B. (2020). Trade finance matters: evidence from the COVID-19 crisis. Oxford Review of Economic Policy, 36(1), 397408.

Demirhan, E. (2020). COVID-19 Küresel Salgininin Türkiye CDS Primlerine ve BíST 100 Endeksine Etkisi. Ankara: Türkiye Ekonomi Politikaları Araștırma Vakfı.

Dündar, M. (2020). COVID-19'un tüketici harcamalarına etkisi. Ankara: Türkiye Ekonomi Politikaları Araştırma Vakfı.

Espitia, A., Mattoo, A., Rocha, N., \& Ruta, M. (2021). Pandemic Trade Covid-19, Remote Work and Global Value Chains. World Bank Policy Research Working Paper 9508.

Fernandes, N. (2020). Economic effects of coronavirus outbreak (COVID-19) on the world economy. SSRN Electronic Journal, 1-29.

Gruszczynski, L. (2020). The COVID-19 Pandemic and International Trade: Temporary Turbulence or Paradigm Shift? European Journal of Risk Regulation, 11(2), 337-342.

Jackson, J., Weiss, M., Schwarzenberg, A., \& Nelson, R. (2020). Global Economic Effects of COVID-19. Washington, DC: Congressional Research Service.

Kumari, M., \& Bharti, N. (2020). Linkages Between Trade Facilitation and Governance: Relevance for Post-COVID-19 Trade Strategy. Millennial Asia, 1-28.
Mann, C. L. (2020). Real and financial lenses to assess the economic consequences of COVID19. R. Baldwin, \& B. W. Mauro içinde, Economics in the Time of COVID-19 (s. 82). Londra: CEPR Press.

Mauro, B. W. (2020). Macroeconomics of the flu. R. Baldwin, \& B. W. Mauro içinde, Economics in the Time of COVID-19 (s. 32). Londra: CEPR Press.

Peker, Y., \& Demirhan, E. (2020). Covid-19 Küresel Salgınının Borsa İstanbul'daki Sektörel Etkileri. Ankara: Türkiye Ekonomi Politikaları Araştırma Vakfı.

Soylu, Ö. B. (2020). Türkiye Ekonomisinde Covid-19'un Sektörel Etkileri. Avrasya Sosyal ve Ekonomi Araștırmaları Dergisi, 7(5), 169-185.

Susskind, D., \& Vines, D. (2020). The economics of the COVID-19 pandemic: an assessment. Oxford Review of Economic Policy, 36(1), 1-13.

ULISA. (2020). Kovid-19 (Koronavirüs) Salginının Ekonomik Etkileri. Ankara: Uluslararası İlişkiler ve Stratejik Araştırmalar (ULİSA) Enstitüsü.

Yıldırım, S. (2011). Türkiye'de Histeri Hipotezinin Geçerliliğinin Çoklu Yapısal Kırılmalı. Akdeniz İBF Dergisi, 11(22), 28-47. 